\title{
Illumination of Wordsworth's Ecological Culture
}

\author{
Huayan Sun \\ Xi'an Peihua University, Xi'an, Shanxi, China, 710100 \\ Email:315112580@qq.com
}

\begin{abstract}
Nowadays we face serious environmental problems such as the haze, the earthquake, the water pollution and so on due to the rapid development of industrialization and urbanization. So this paper analyzes the ecological culture from the literary works of Wordsworth, try to get some illumination for solving environmental crisis and wake up the ecological consciousness of human beings. According to illustrating the relationship between Man and Man, Man and Society, Man and Nature form the poems: "I Wander Lonely as a Cloud", "Tintern Abbey" and other short poems, this paper demonstrates the importance of harmony between Man and Nature. To integrate the ecological culture and literary works is the innovation of this paper.
\end{abstract}

Keywords: William Wordsworth, ecological culture, harmony, nature

\section{Introduction}

With the rapid development of industrialization and urbanization, the environmental crisis is getting more and more severe. So ecological culture is paid a lot of attention. And Wordsworth has been generally acknowledged by Western ecological critics as the first romantic poet who had ecological consciousness. Wordsworth developed a keen love of nature as a youth and he visited many beauteous places. According to the subjects, Wordsworth's short poems could be classified into two groups: poems about nature and poems about human life. It was nature that gave him "strength and knowledge full of peace." He once said, "Nature is everything to me". He thought the image of nature could provide a space for the young's heart to think and love. In his opinion, nature had affection and inspiration. And even the smallest and most common subject had their own spirit. Nature under his pen had similar spirit and character, the same statue and freedom because he regarded nature as his friends and teachers. He believed that nature could enrich man's affection and gave people warning of life. [3] So analyzing Wordsworth's poems is significant to the ecological culture.

\section{Wordsworth's Ecological Culture}

Ecological culture refers to the knowledge of the law of the nature's variety. It goes through four periods. In the first period, man passively got used to the nature. In the second period, people were the slave of the nature. In the third period, people intended to conquer and control the nature. In the fourth period, people got harmoniously with the nature.

Wordsworth is regarded as the most famous nature poet in England, and the enlightener of environmental conservation. In his writing, he pays great concern about the relationship between Man and Man, Man and Society, and Man and Nature.

2.1 The Relationship between Man and Man Represented in the Poem "The Solitary Reaper" As for Wordsworth, nature was the trinity of humanity, rationality and deity. So Wordsworth believed that man should follow God's instruction to love his kinsman and love all non-human beings on the earth. He required people to respect the others and to be friendly to the others. And the idea of Pantheism was well displayed in Wordsworth's works. In other words, Wordsworth had paid a kind of homage to his "omnipresent spirit" in nature.

In the poem "The Solitary Reaper", the song of the young girl reaping in the fields is incomprehensible to him, and he appreciates its tone, its expressive beauty, and the feeling it gives to him, rather than its content, at which he can only guess. As she "cuts and binds the grain," she "sings a melancholy strain", and the valley overflows with the beautiful, sad sound which is nicer than any chant of the nightingale to weary travelers in the desert. Whatever she sings about, he says, he 
listened "motionless and still". And as he traveled up the hill, he carried her song with him in his heart long after he could no longer hear it. He says that anyone passing by should either stop here, or "gently pass" so as not to disturb her. In his poem, it shows that people should care and show sympathy and pay close attention to each other no matter who he is. People should respect and appreciate each other.

\subsection{The Relationship between Man and Society}

Man lives in the society. And society, especially the important social events, influences man's mind and spirit deeply. Wordsworth's thoughts were greatly influenced by the Industrial Revolution and the French Revolution. The Industrial Revolution promoted the social development, however it corrupted public morals and greatly spoiled people's spiritual world. It led to great gap between the rich and the poor which resulted in the social instability. The failure of the French Revolution destroyed the ideal of "liberty, equality and fraternity". They realized that violent revolutions would lead to social turbulence and moral crisis. So the European intellectuals, especially those English Lake Poets including Wordsworth, turned from radical revolutions to nature for comfort. So the development of the society has great influence to Man's spiritual world.

\subsection{The Relationship between Man and Nature}

According to Bible, Nature and Man are both created by God, so they should enjoy equal treatments. Marx once said that "Man and Nature are unity in nature". Man and Nature should be harmonious. From an ecological perspective, the reader could find that the most obvious feature of Wordsworth's poetry was that he understood the close relationship between Nature and Man.To Wordsworth, nothing in nature was dead. Instead, nature had a living spirit which observed and guided Man and his external world: the daffodils tossing their heads in sprightly dance. ("The Daffodils"); the flowers enjoying the air they breathe ("Lines Written in Early spring"). All the forms of nature in his poetry were pulsed with life. He saw them glow, breathe and speak. So man had to respect nature and worship her as he worships a God. " [1] Therefore, Man, as a part of nature, should be a modest student to nature and learn from it. Wordsworth made an enthusiastic appeal asking his friends to "quit your books", and went to nature "into the light of things" ("The Tables Turned"). Here in the poems, what he wrote taught the readers to appreciate and respect nature as a living community instead of an object. To put it in a term used in modern medial and academia, his works reveal his "ecological consciousness".

\subsubsection{The Harmony between Man and Nature Represented in the Poem "I Wandered Lonely as a Cloud"}

In the poem "I Wandered Lonely as a Cloud", Wordsworth shows the harmony between Man and Nature. He rejects human-centralism. He believes that Man is a part of nature rather than the host of nature. He has a loyal heart to nature. In the poem, the speaker is reminiscing about a day when he was out walking and suddenly he saw a host of daffodils. The daffodils seem to have human beings' feeling. The poet always sees the daffodils appear before his eyes. It is the daffodils that comforted his inner world. The daffodils are the poet's partner when he feels lonely and helps him pass the worst period of his life.

In the first two lines "I wandered lonely as a cloud/ That floats on high o'er vales and hills," the speaker applies the image of a cloud to himself, which symbolizes his integration with the natural world. Both he and the cloud are aspects of the world, which is subject to the laws of nature but they can still retain their freedom in spite of this. The dancing flowers, the lake, the breeze and the continuous stars also stress the freedom and prove with "self-joy" and contended solitude. The last part created a state a harmony between Man and Nature. People can get pleasure and wonderful feelings from nature, but nature supplies Man not only with the pleasure but the desire of plunder and human existence. Nature can affect man's emotion and behavior with its motion and sound. Wordsworth uses various natural phenomena, such as clouds, daffodils, stars and waves, as devices to characterize his emotion and feeling at different stages. This poem discloses the relationship between nature and human beings: how nature can affect man's emotion and behavior with its motion and sound. It might also be understood as a quest to overcome the rift between the world of inner and outward reality. 


\subsubsection{Man's Worship of Nature Represented in the Poem "Tintern Abbey"}

In poem "Tintern Abbey", the poet showed Man's worship of Nature. He depicted the marvelous effect of nature to him. The author expressed the charming of nature and showed his feelings of nature in order to wake up people's love. People should return to the nature. Tintern Abbey gave us wonderful feelings on hearing and seeing. When, as a boy, he "bounded over the mountains" and "through the streams". Nature made up his whole. And now he can sense the presence of something from the setting suns, the ocean, the air itself, and even in the mind of man. This energy seems to him "a motion and a spirit that impels/All thinking thoughts.../And rolls through all things." For that reason, he still loved nature, mountains and pastures and woods. The line "Here, under this dark sycamore, and view" does not quite conform to the stress-patterns of the meter, but fits into it loosely, helping Wordsworth approximate to the sounds of natural speech without grossly breaking his meter. The idea is reinforced by the speaker's description of the power he feels in the setting sun and in the mind of man, which consciously links the ideas of God, Nature, and the human mind---as they will be linked in Wordsworth's poetry for the rest of life, from "It is a beauteous evening, calm and free" to the great summation of the "Immortality Ode".

\subsubsection{Influence of the Beauty of Nature on Man Represented in the Poem"Composed Upon Westminster Bridge"}

In the poem "Composed Upon Westminster Bridge", The poet describes the beauty of the city of London at sunrise. Wordsworth is standing on Westminster Bridge, which crosses the River Thames, a wide and very slow flowing waterway that serves as a harbor for the city. The poet is caught up in a feeling of awe and rapture. Wordsworth showed the beauty of nature's influence on Man. In the first line, "Earth has not anything to show more fair." Here earth is personified as a being that has possessions who can show off, for example, its cities. In the fourth line, "This City now doth, like a garment, wear," the city is then personified as a person wearing a fine robe. The sixth line "Ships, towers, domes, theaters, and temples lie" contains the breathtaking imagery of a primitive skyline in a clear, morning sky. The imagery in line eight "All bright and glittering in the smokeless air." calls to mind the image of endless clearness, endless purity. All throughout the poem, Wordsworth uses his trademark references to nature, painting the beautiful picture in the reader's mind. The river is personified in line twelve showing relatedness in the view of the city. "The houses seem asleep" in line thirteen, a definite personification: it serves to show that in the tranquility of the city, there cannot be a worry stirring in the heart, only peace. London of Wordsworth's day would have been a heavily polluted city. Smoke from thousands of fires would have blackened the atmosphere and darkened the building with soot. On this particular morning, however, the air is smokeless so that everything appears bright and glittering in the light of the rising sun.

\section{Illumination}

Wordsworth had a profound understanding of nature's value. He highly regarded nature as "the anchor of thought, the nurse, the guide, the guardian of heart, the source of happiness and wisdom". $\mathrm{He}$ foresaw the dilemma of human existence, and tried to solve this problem by means of poetry. $\mathrm{He}$ resolved to save man's soul and human nature. He tried to achieve ecological balance on the earth and in human mind.

In his poems, we can experience the beauty of Nature, the harmony between Man and Nature, and the social influence to Nature. In order to satisfy people's own interests, they exploit the nature crazily, so the balance between nature and human beings is destroyed. Man has already received severely punishments and realized the importance of protecting the environment. Wordsworth's poems called for the people to protect the nature and woke up man's mind from the dream of money or other material things. The illumination of Wordsworth's poems is to cut the ideological root of environmental destructions, to improve the alienated Man---Nature relationship, to amend the polluted nature and to prevent spiritual pollution. It assists to achieve sustainable development and build a harmonious society. 


\section{Conclusions}

According to analyzing the deep influence among Man, Society and Nature, it shows the central role of Nature. Once Man destroys the law of nature, they will receive the punishments of Nature. It's more popular to study the ecological culture. By the beautiful feelings the literary works provided, Man are motivated to protect the environment. And the academic circle of literary theories starts to reconsider literary works from the ecological perspective, tries to find a new way from literary works to solve the environmental crisis. Wordsworth believed nature was the trinity of humanity, rationality and deity. Nature was the teacher and the guider of the human. So it is of great significance to reinterpret Wordsworth's works from this point of view. Wordsworth formed a unique concept of nature, which contained the aspects of natural sublimity, natural cruelty and natural beauty. This concept had both aesthetic significance and ecological significance. He believed that since the sublime offers emotions of exaltation and awe, man should adopt a humble and modest attitude toward nature. He had a profound understanding of nature's value. He highly regarded nature as "the anchor of thought, the nurse, the guide, the guardian of heart, the source of happiness and wisdom". In his opinion, natural beauty symbolized love and gentleness, so it was the best medicine for man's wounded soul. He cared for the masses, their material life and spiritual life. He foresaw the dilemma of human existence, and tried to solve this problem by means of poetry. He resolved to save man's soul and human nature. He tried to achieve ecological balance on the earth and in human mind. As a great poet, thinker, and philosopher, Wordsworth is a complicated figure to deal with. In general, this thesis is a meaningful attempt in the study of Wordsworth's ecological consciousness because it is written from new aspects. As to how to put these theories into practice, we should combine the reality and ask more people to concern the environment problems. Create more beatiful images from the poems to arouse people's love to Nature. So the study of the ecological culture is significant to the environment.

\section{References}

[1] Bate,Jonathan, Romantic Ecology. New York: Routledge. (1991)

[2] Buell Lawrence. The Future of Environmental Criticism.Cambridge:Blakewell Publisher. (2005)

[3] Boxiang Zhang, Directions of English Literature. [M] Wuhan University Press.(2006)

[4] Wordsworth, Preface to Lyrical Ballads. [M] Beijing: People Press.(1961)

[5] Joshua Stanley. Wordsworth and "the most unhappy man of men": Sentimentalism and Representation[J]. European Romantic Review,2015,26(2):.

[6] Kuei-Hsien Liao,Jeffrey Kok Hui Chan. What is ecological wisdom and how does it relate to ecological knowledge?[J]. Landscape and Urban Planning,2016,:.

[7] Chaojun Wang,Hongrui Zhao. The Assessment of Urban Ecological Environment in Watershed Scale[J]. Procedia Environmental Sciences,2016,36:. 